\title{
Os Itinerários da Selva: na Amazônia
}

\section{Maria José de Queiroz}

«I'd be an Indian here, and live content to fish, and hunt, and paddle my canoe, and see my children grow, like young fawns, in health of body and peace of mind, rich without wealth, and happy without gold».

(A. R. WALLACE, Travals on the Amazon and Rio Negro)

A selva, que julgávamos definitivamente perdida para a nossa compreensão, tão distante nos parece das nossas modestas inquietudes urbanas, defendida da civilização e da técnica, ei-la nas páginas dos diários: a sua intimidade devassada, os seus mistérios desvendados, a ecologia em pânico. Alargam-se os limites do mundo civilizado. Escreve-se hoje, na Amazônia, o mais fascinante capítulo da história da conquista e da colonização. $\overline{\mathrm{E}}$ tempo de epopéia. Os atuais desbravadores - mateiros, operários, humildes, empreiteiros, construtores, colonos - respondem, sem suspeitá-Io talvez, ao apelo do espírito de fronteira - "The frontier mind", cuja importância foi encarecida por Frederick Jackson Turner em estudo clássico sobre o pioneirismo americano.

Quem primeiro viu no vale amazônico uma das mais extensas fronteiras tropicais modernas foi Charles Wagley no seu livro Uma comunidade amazônica. ${ }^{\perp}$ A Belém-Brasília, a Transamazônica,

1. Charles Wagley, Uma comunidade amazônica. Estudo do homem nos trópicos. Trad., São Paulo, Companhia Editora Nacional, Brasillana, 1957, série $5^{4}$, vol. 290, p. 20. 
a Cuiabá-Santarém, a Perimetral Norte crismam, no risco em cruz do trator e do asfalto, a exatidão desse batismo. $\tilde{\mathrm{E}}$ a selva a nossa última fronteira ou, como queriam Humboldt, Euclides da Cunha e José Eustasio Rivera a última página inédita do Gênesis.

Advirta-se, com justiça, que aos portugueses, atentos e ciosos do território descoberto, não lhes esquecera a necessidade de povoar a fim de legitimar a posse, nem, tampouco, a obrigação de colonizar para legitimar direitos. A Amazônia tem sido, valha-nos a lição da história, fronteira onipresente nos destinos de Espanha e Portugal. Francisco de Orellana, ${ }^{2}$ o primeiro a cruzar o rio-mar em 1542, vinculou-lhe o nome à lenda das mulheres guerreiras, estranhas habitantes das margens do rio Caimé, ao sul do Solimões, entre o Ucaiale e o Madeira. O encontro do conquistador com uma tribo indígena, armada de arcos e flechas, os cabelos longôs, ao vento, tornou-se motivo de repetidas reelaborações míticas. A vista do grupo aguerrido, veio-lhe, com certeza, à imaginação, outro quadro: o das margens do Termodonte, na Capadócia. Em resposta ao inesperado lapso da fantasia, o bravo espanhol batizou com

2. Sobre a expedição de Orellana, vejam-se: Bautista Ramusio, Delle navigatione et viaggi in molti luoghi ... Veneza, 1554; Agustín de Zárate, Hostoria del descubrimiento y de la conquista del Perí. Madri, 1886 (a primeira edição é do século XVI); Francisco López de Gomara, Historia general de las Indias. Madri, 1877 (a primeira edição é, também, do século XVI); Garcilaso de la Vega, el Inca, La Florida. Madri, 1723 (a primeira edição é de 1605); Antonio Herrera, Historia general de los hechos de los castellanos en las istas $i$ tierra firme del Mar Océano. Madri, 1601; Simão Estácio da Silveira, Relação sumária das coisas do MKaranhão. Lisboa, 1624; Cristóbal de Acuña, Nuevo descubrimiento del gran Rio de las Amazonas. Madri, 1641 (Consulte-se o volume 203 da Brasiliana, série 2", tradução e notas de C. de Melo-Leitão: Gaspar de Carvajal, Alonso de Rojas e Cristóbal de Acuna, Descobrimentos do Rio das Amazonas. São Paulo, Companhia Editora Nacional, 1941); Charles Marie de la Condamine, Relation abrégée d’un voyage fait dans l'intérieur de l'Amérique Méridionale... Paris, 1945 (Cf. tradução de Aristides Ávila, Relato abreviado de uma viagem pelo interior da América Meridional. São Paulo, Ediçñes Cultura, 19 série Brasílica, 1944); G. F. de Oviedo, Historia general y natural de las Indias. Madri, 1855, IV; José Toribio de Madina, Descubrimiento del Rio de las Amazonas. Sevilha, 1894; André Thévet, Singularidades da França Antártica, a que outros chamam de América. Trad., São Paulo, Companhia Editora Nacional, Brasiliana, 1944, série 5", vol. 229 . 
nomes tupis as fabulosas guerreiras que se chamavam, na Antigüidade Pentesilea, Antíope, Valestris, Tomiris... Alexandre Humboldt ${ }^{3}$ insere esse relato na tradição romanesca tomando-o, provavelmente, a La Condamine (1745). Afirma tê-las encontrado no Solimões, entre Tefé e a embocadura do Purus. Também Raleigh, no século XVI, insistira na divulgação da lenda. As amazonas viviam, na sua notícia, ao sul do Maranhão, na província de Tapajós. Testemunhas dignas de crédito lhe haviam assegurado de suas imensas riquezas - baixelas e objetos de ouro, adquiridas a troco das milagrosas pedras verdes, muiraquitãs, famosas pelas suas virtudes curativas. O mais curioso é que La Condamine, cem anos depois, descobrisse, ainda em poder dos índios, grande número dessas pedras, herdadas, como declaravam, dos seus antepassados, amigos ou amantes das mulheres sem marido que obedeciam apenas a uma principal - condori ou conhori. ${ }^{4}$

O mito das amazonas difundiu-se em numerosas crônicas de viagem. O rio, inicialmente cognominado Orellana, acabou por denominar-se rio das Amazonas, prova evidente e efetiva do seu prestígio. O próprio Humboldt, inteiramente consagrado à ciência e zeloso, sempre, da verdade, esquivou-se a negar a lenda: preferiu explicar que não se destituía de fundamento a tradição veiculada pelos primeiros conquistadores.

O vale amazônico, exótica região de sombras, árvores e lianas, despovoado, já, de suas belicosas habitantes, continuou a abrigar, no correr do tempo, alguns dos mais caros mitos da humanidade. Avulta, entre todos, o de $E l$ Dorado. As referências às riquezas do reinado do Paititi aparecem a partir de 1549, à chegada de trezentos índios do Brasil a Chapapoia. Alfred Métraux, nas Migrações históricas dos tupis-guaranis (1907), nota que todas as expedições à bacia do Amazonas visavam ao descobrimento da terra maravilhosa, cuja abundância de pedras e metais preciosos fora largamente propalada pelos índios imigrantes. O dilatado

3. Viaje a las regiones equinocciales del Nuevo Continente. Hecho en $1799,1800,1801,1802,1803$ y 1804 por A. de Humboldt $y$ A. Bonpland. Trad., in: Viajes por América del Sur. Madri, Aguilar, 1962, II.

4. Charles Marie de la Condamine, Relato abreviado de uma viagem pelo interior da América Meridional, trad. cit., p. 66-69. 
eco dessas lendas, associadas, todas elas, à tradição do Dorado - príncipe do reino amazônico que, em dia de sagração, coberto de pó de ouro, se banhava num imenso lago ao qual os seus súditos lançavam, em ofertório, pesada carga de jóias deslumbrantes inspirou enredos fantasiosos, acendeu as ambições hispânicas. D. André Hurtado de Mendoza, Marqués de Cañete, rendeu-se também à tentação do ouro. Animado pelo desejo da conquista, autorizou D. Pedro de Ursúa a armar soldados e cavaleiros, a convocar índios e formar tropas a fim de tomar posse do país da abastança. O infeliz conquistador, herói de muitas batalhas, triunfador da rebelião do Panamá, sucumbiu, a meio da travessia, em 1560, vítima da cobiça de um dos seus capitães, Fernando de Gusmán, que se fez nomear primeiro Príncipe do Peru. Frustrou-se, portanto, em sangue e desgraça, o sonho do Marquês. Ao findar a busca de El Dorado não se encerrou contudo a expedição. Lope de Aguirre assume o poder e passa a chamar-se "Forte caudilho dos Maranhões". O seu itinerário, do rio Negro ao Orinoco, para chegar ao mar, alcança as dimensões da mais desnastrada alucinação mental. No seu furor desvairado, Aguirre blasfema contra Deus, seu inimigo, e desafia a Felipe II. Aos que o seguem impõe, a ferro e sangue, tirania hedionda. Sabendo-se perseguido pela justiça, apunhala a própria filha para salvá-la da prisão. Werner Herzog, jovem cineasta alemão, reelaborou a história do caudilho dos Maranhões no filme Aguirre ou a cólera de Deus, lançado há pouco em Paris. A febre do ouro, origem da loucura do conquistador espanhol, oferece a Herzog excelente matéria para o estudo do mito de $E l$ Dorado bem como lhe permite figurar no cenário insólito do inferno verde os pesadelos alucinatórios do traidor cuja divisa "el mundo es poco" justificava desmandos e arbitrariedades.

A muitos, muitíssimos mais, a selva embaraçou os passos, emaranhou a vida, no desnorteio dos caminhos alagados e sombrios. A ninguém desvendou, jamais, o segredo do príncipe encantado, esplêndido de ouro no meio do prodigioso lago equatorial. Para os temerários, como compensação das canseiras, doenças e fome, preservara prêmio maior: a flora magnífica, de raras e desconhecidas emoções. Exemplo desse inesperado alumbramento, dom 
superior à contemplação do Dorado, divulga-o D'Orbigny (1828) ao relatar a comovida genuflexão de um missionário espanhol, companheiro de viagem do naturalista Haenke, extasiado diante da "mais admirável criação da Divina Providência - a vitória-régia".

O guaraná, ou uaraná, de uso remoto na Hiléia, só se tornou conhecido no século XVIII, após o comércio dos brancos com as tribos indígenas do baixo Amazonas. A sua ação estimulante, aliada às suas qualidades terapêticas, popularizoumo em toda a extensão do grande rio. A palmeira, e particularmente o miriti, muriti, buriti, conhecida como "a árvore da vida" ou "o saguzeiro da América", conforme Humboldt, é outro presente com que a flora brindou o conquistador para consolá-lo da perda do Paititi. "Avistá-la de longe, na aridez dos grandes chapadões, é ter, na opinião de Gastão Cruls, "a certeza da boa aguada, da cabeceira acolhedora, do olho d'água dessedentante".5 Couto de Magalhães aponta-lhe outro mérito - o de servir de sinaleiro entre as tribos. Na sua Viagem ao Araguaia conta que os índios envolvem o buriti com faixas superpostas de capim verde, guardada a distância de um palmo. Após a descida do alto tronco ateiam fogo à última faixa. Então, sucessivamente, entram em incandescência todas as demais. A palmeira, farol luminoso, leva ao amplo vale a mensagem de luz e fumo escrita no céu em densa e cambiante espiral.

As orquídeas, com mais de duzentos gêneros definidos, abrem, exaltadamente, o capítulo dos prodígios da natureza amazônica. Elas, sim, logram, na sua exuberância, superar o deplorado tesouro escondido da mítica Manoa.

A pobreza da fauna local que, de início, desapontou o conquistador, ávido de arrebatamentos, não tardou a sugerir ao viajante e ao cronista, na tentativa de superar carências, a criação de uma zoologia fantástica. Os primeiros cartógrafos pintaram leões, rinocerontes, tigres e javalis ferozes nos igarapés e clareiras da selva selvaggia que ainda hoje assusta e amedronta o civilizado. Como se isso não bastasse, povoaram a floresta de animais fabulosos e seres medonhos: pigmeus, gigantes, índios que caminhavam

5. Gastão Cruls, Hiléia amazônica. $2^{\natural}$ ed., São Paulo, Companhia Editora Nacional, Brasiliana, 1955, série $5^{\mathrm{a}}$, vol. 6, p. 53 . 
ao revés, mulheres que se acasalavam com búgios. Além dessas lendas, de clara procedência européia, divulgadas por penas ilustres, outras muitas circularam, e ainda circulam, de sabor indígena, autóctones, a da Iara, sereia sedutora das águas doces; a do Curupira, diabólico extraviador de caminhos; a do Anhangá, veado de olhos de fogo que enlouquece os caçadores atrevidos; a de Canaima, Macunaima ou Macunaíma, deus frenético, princípio do mal e causa de todos os males, sempre em luta com Cajunha ou Cajuña, o bom; a da indiazinha Mapiripana; a do Boiúna, da Cobra Grande, do Boto, da Cunhã, do Panema etc. etc.

O rio, com o seu imenso caudal, é testemunha fluente do amor impossível da lua e do sol. As lágrimas da lua, mãe dos vegetais na mitologia amazônica, desceram do contraforte da cordilheira de Santa Ana, no distrito de Huanuco, alargaram-se no vale verde para afogar o desespero nas águas salgadas do Atlântico. Essa, a mais bela ficção indígena. Os forasteiros encarregaram-se de transportar, mundo afora, a própria versão a respeito do rio-mar e do seu vasto território. Inferno de muitos, paraíso de poucos, terra imatura, universo misterioso e exótico, refúgio dos desvios da imaginação, a Amazônia atravessou o século XIX e chegou ao século XX, a despeito de abundante bibliografia, quase totalmente ignorada. No entretanto, cabe repetir com Araújo Lima que a Amazônia "não é terra misteriosa nem paradoxal: é simplesmente uma terra lastimavelmente fraudada e saqueada." 6

Alceu Amoroso Lima nela vê, lucidamente, "terra deserta, terra a ser povoada. Afigura-se muito agressiva e indomável. Não há, diz ele, uma agressividade específica e característica da terra; o homem é que se torna muito vulnerável pela insuficiência numérica. Não está em causa a qualidade da terra, mas a quantidade de gente". 7 Nada em realidade justifica o apelido que lhe atribuíram de "terra imatura".8 Mais justo seria, observa Paul de Cointe, chamá-la "terra das lendas", ou, melhor ainda, como

6. Araújo Lima, Amazônia - a terra e o homem. $3^{\text {* }}$ eđ., São Paulo, Companhia Editora Nacional, 1945, p. 83.

7. Prefácio ao livro de Araújo Lima, cit., p. 8.

8. Cf. Alfredo Ladislau, Terra imatura. 
escreveu Frederic Harrt, "terra incógnita", qualificativo que muito em breve não lhe será, por certo, aplicado. ${ }^{9}$

Resta saber: a intimidade do civilizado com a floresta, com os seus índios, com os seus rios e mistérios, que visão oferecerá da Amazônia? O "saber de experiências feito" inspirará, finalmente, o nosso romance da selva? Por quanto tempo o "inferno verde", a que se refere Alberto Rangel, nos esconderá os segredos a que têm acesso os índios taciturnos, o cabloco curtido e os brancos aventureiros? Até quando endossaremos, sem esperança de réplica, o juízo de Eduardo Frieiro para quem "não apareceu ainda o romancista brasileiro que animasse, que humanizasse aquela grandiosa paisagem com a presença do homem na luta angustiosa contra a bruteza das forças elementares"? 10 "A floresta deste país de florestas, continuará, como reclamava Monteiro Lobato, sem o seu pintor e o seu intérprete" ? 11 O romance dos seringueiros humildes, a dolorosa odisséia dos brabos miseráveis, perdidos na verde monotonia da variedade infinita das árvores e trepadeiras, escreveu-o, na nossa língua, um português, Ferreira de Castro; em espanhol, o colombiano José Eustasio Rivera e o venezuelano Rómulo Gallegos; em inglês, o argentino por adoção, Guillermo Enrique Hudson; em alemão, A. Döblin e Arnold Höllriegel. Apenas nos referimos, é óbvio, aos grandes romances da selva, àqueles em que a natureza, opressiva e tentacular, assoma como personagem central, domina a narrativa, impondo-se tanto ao autor como aos protagonistas. Não obstante as diferenças de estilo e de época, as peculiaridades de interesse, de forma e conteúdo, cabe assinalar, nas obras citadas, uma coincidência: a fascinação da terra inculta e áspera que magicamente subjuga quantos dela se

9. Paul de Cointe, o Estado do Pará: a terra, a água e o ar. A farina e a flora. Minerais. São Paulo, Companhia Editora Nacional, Brasiliana, 1945, série $5^{n}$, vol. 5, p. 13 .

10. Eduardo Frieiro, A ilusão literäria. Belo Horizonte, Livraria Editora Paulo Bluhm, 1941, p. 131.

11. Monteiro Lobato, $A$ barca de Gleyre (Correspondência entre Monteiro Lobato e Godofredo Rangel). 12* ed., São Paulo, Editora Brasiliense, 1968, I tomo, p. 279-280. 
aproximam. Nas obras de Augusto Roa Bastos (Hijo de hombre, 1960) e Mario Vargas Llosa ( $L a$ casa verde, 1964) a selva empresta cenário às angústias das personagens. A natureza, circunstância habitada, não lhes inibe o livre exercício da vontade, da inteligência e da emoção. Dispensamos por isso a sua inclusão entre os autores antes mencionados.

Para os críticos literários essas histórias devem estudar-se em capítulo à parte, consagrado ao regionalismo e aos enredos de aventuras. Assim La vorágine (1924), de José Eustasio Rivera, Das Urwaldschiff, ein Buch von Amazonerstrom (1929), de Arnold Höllriegel, A Selva (1930), de Ferreira de Castro, Canaima (1935), de Rómulo Gallegos, Das Land ohne Tod (1937), de A. Döblin. Em todos esses romances a ficção se mistura às ciências naturais, à história e à cartografia, à epopéia e ao mito, à sociológia, ao costumbrismo, ao indianismo e ao indigenismo. Dentre os seus autores, convém lembrar, apenas Hudson e Döblin (talvez porque professassem uma forma de utopismo à Rousseau) vêem na selva - paraíso perdido, a sonhada Idade de Ouro da felicidade e da paz, o beatus ille da Antigüidade clássica. Naturalista sensível, adepto do campo e da liberdade, Green Mansions ${ }^{12}$ serviu ao escritor inglês de protesto contra a civilização corrupta que tem na cidade a sua melhor expressão. Döblin, informado por pesquisa fecunda na Biblioteca Nacional de Paris (de 1934 a 1937), apresenta visão exuberante da natureza americana. A luz do mito aborígene da existência de um país edênico, situado na direção do sol poente, cria a terra sem morte - Das Land ohne Tod, onde cresce a árvore da vida e de onde se baniram o trabalho, o sofrimento e a maldade. Arnold Höllriegel vale-se da expedição de Orellana para percorrer o vale amazônico recuperando para o expressionismo alemão o cenário exótico, a história e a mitologia da terra das amazonas. Bem distinta é a visão dos demais escritores, comprometida com a emergência da selva e com a vida dos seus habitantes. Ferreira de Castro, que a freqüentou, adolescente ainda, como imigrante, explica: "Ali tudo perdia as proporções

12. Mansiones verdes, na tradução espanhola. Foi transformado em filme com excelente trilha sonora de Vila-Lobos. 
normais. Olhos que enfiassem pela primeira vez no vasto panorama, recuavam logo sob a sensação pesada do absoluto, que dir-se-ia haver presidido à formação daquele mundo". ${ }^{ \pm 3}$. Rómulo Gallegos, em Canaima, fala do curso dos grandes rios da Guiana e do labirinto fluvial que invade o bosque intrincado em cujos igarapés só se aventuram os rumberos (buscadores de rumbo, rumo, ou baqueanos). O "racional", inábil e despreparado, dificilmente consegue sobreviver ao assalto das forças naturais. Atraem-no, fatalmente, os abismos do pânico. A emoção do medo, diante das mil pupilas assombradas que o contemplam dentro da noite eterna, feita de folhas e ramos, acaba por desesperá-lo. $\mathrm{E}$ é o medo que lhe desmoraliza a vontade, lhe desnorteia a razão e, por fim, o enlouquece. O protagonista de Canaima, Marcos Vargas, somente logra vencer os malefícios da selva mercê de tormentosa iniciação ao mundo abismal. Mas todo aquele que transpõe os seus limites começa a ser, assegura-nos Gallegos, "algo más algo menos que hombre". 14 De fato, José Eustasio Rivera que conheceu, de vista de ojos, a Amazônia, e chegou a transpor, por experiência, as fronteiras da razão no delírio intermitente da febre, vincou fundo, nas suas criaturas, a garra da selva. Os tipos descritos em La vorágine ${ }^{15}$ são, realmente, "algo mais algo menos que homens": seres além do bem e do mal.

13. Ferreira de Castro, A Selva, in Obra Completa. Rio de Janeiro, Editora José Aguilar, 1958, vol. 1, cap. IV, p. 125.

14. Rómulo Gallegos, Canaima. $6^{n}$ ed., Buenos Aires, Espasa-Calpe Argentina, S.A., Colección Austral, 1951, cap. XII, p. 162.

15. La vorágine, de José Eustasio Rivera (Neiva, Colômbia, 1888-1928, Nova Iorque), publicou-se em Bogotá, em 1924, após o aparecimento de dois artigos do autor contra as miseráveis conđiçōes de vida dos caucheiros colombianos na selva amazônica («La concesión Arana y los asuntos con Venezuela», El Espectador, 26-05-1924, e «Falsos postulados nacionales», EI Nuevo Tiempo, 28-08-1924). Em 1922, como secretário de uma das comissóes de demarcação de fronteiras entre a Colômbia e a Venezuela, Rivera percorrera toda a região banhada pelo Orinoco até Ciudad Bolívar e atravessara os lhanos até San Fernando de Atabapo. Atacado pelo impaludismo permaneceu algum tempo em Yavita de onde passou a Maroa e Victorino. Desceu, em seguida, ao vale dos rios Negro e Casiquiare: Concluiu a sua missão em Manaus. Ã vista das atrocidades cometidas pela Casa Arana, o escritor, indignado, apresentou relatório contundente ao governo. Denunciou, extensa- 
Uma das suas personagens mais acabadas, Clemente Silva (o nome - Clemente, identifica-o como aquele que pede clemência e o apelido - Silva, situa-o na sua circunstância, a selva) declara: "Fui caucheiro, sou caucheiro! [...] A mil léguas do lugar onde nasci, amaldiçoei as recordações porque todas são tristes: a dos pais que envelheceram na pobreza, esperando o apoio do filho ausente, a das irmãs de beleza núbil que sorriem às decepções, sem que a fortuna mude a cara, sem que o irmão lhes leve o ouro restaurador.

"[...] Aquele que tentou elevar-se caiu vencido ante os magnatas indiferentes, tão impassíveis como estas árvores que nos contemplam morrer de febres e de fome, entre sanguessugas e formigas!" 16

Instaura-se, no romance, o processo da selva. Não se lêem, à entrada da floresta áspera e forte, as "palavras escuras" do poema de Dante - "Lasciate ogni speranza voi ch'entrate!" A vertigem do abismo, a ambição do lucro, o apelo do desconhecido colhem o incauto viajante, atento apenas aos próprios desígnios. A pouco e pouco o envolve a natureza inexorável. Inútil se torna, à míngua de recurso, qualquer tentativa de libertação. "Deixa-me fugir $[\ldots]$ de tuas penumbras doentias, formadas com o hálito dos seres que agonizam no abandono da tua majestade", geme o pobre condenado. "Deixa-me voltar para a terra de onde vim, para desandar esta rota de lágrimas e sangue que percorri em dia nefando",17 suplica sem resposta. Além da escravidão ao trabalho, ou aos seus empresários — donos de tudo e de todos, há a escra-

mente, as atividades ilegais do comércio da borracha e a exploração desumana da mão-de-obra. Em virtude da corajosa defesa dos interesses nacionais, Rivera foi nomeado em 1925 membro da Comisión Investigadora encarregada de apurar os crimes praticados contra a economia colombiana. Nos Estados Unidos, em 1928, ainda em missão oficial, veio a falecer em conseqüência de uma hemorragia cerebral causada pela malária contraída durante a permanência na selva. Duas obras asseguram-lhe a posteridade literária: Tierra de promisión (versos), de 1921, e La vorágine.

16. La vorágine. $6^{*}$ ed., Buenos Aires, Editorial Losada, S.A., p. 169.

17. Id., ibidem, p. 96 . 
vidão à selva, tirânica, implacável, devoradora. Ā sua voragem, ninguém escapa.

Uma confissão abre La vorágine: "Antes que me apaixonasse por qualquer mulher, joguei o meu coração ao acaso e ganhou-o a violência". ${ }^{18}$ Ante o desafio do destino, o autor oferece ao protagonista, nel mezzo del cammim, a evasiva da violência da selva. Sob o signo do jogo - azar, sina - cumpre-se o trânsito de Arturo Cova e Alicia, a sua amante. A trama obedece, como nos livros de viagens, às solicitações da emergência. À travessia, cada passo supõe perda de direitos, submissão, alienação à floresta e aos seus demiurgos. O "racional" - título que se confere ao branco civilizado - despojado da condição humana, ferido e diminuído, recupera, sem quase dar por isso, modos, necessidades e carências animais. Cova, como as demais personagens, desvincula-se das virtudes urbanas e adota o comportamento selvático.

Ao despedir-se da cordilheira, logo à entrada dos lhanos, os dois protagonistas encontram, à sua espera, o velho D. Rafael (cuja missão lembra a do arcanjo encarregado de conduzir Tobias ao país dos medos), que lhes serve de guia até a fazenda $L a$ Maporita onde, ao apelo da selva, se rendem ao destino nefasto. Abandonado pela amante, a primeira a sentir a tentação do desconhecido, Cova deixa-se conduzir pelo fatum irrevocável. Com alguns amigos, põe-se a caminho. Repetem eles, na sua determinação, os homens da conquista, "sin otro delito que el de ser rebeldes, sin otra mengua que la de ser infortunados".19 Num barco que imita, na cor e na forma, lúgubre ataúde, seguem, água abaixo, "um caminho escuro que se movia em direção ao vórtice do nada". Não nos será difícil adivinhar nesse rio "sem ondulações, sem espumas", mudo e tétrico, o Lete sombrio. Para trás, as lembranças, os contornos nítidos, a luz. Encarrega-se o próprio autor de oferecer-nos, na visão da personagem, o progressivo apagar da memória, ao dissipar-se, no crespúculo, "os perfis do bosque estático, a linha imóvel, as silhuetas dos remeiros [...]" 20

18. Id., ibidem, p. 11.

19. Id., ibidem, p. 97 .

20. Id., ibidem, p. 98 . 
A voragem instala-se no enredo, toma residência na vida de Arturo e na de todos que o acompanham. Excita-o o desejo de vingança. Barrera, o sedutor de Alicia, a quem busca em desespero, aparece na verdade como barreira a destruir: "Yo era la muerta y estaba em marcha!", exclama num ímpeto de ódio.

A selva, de alcatéia, espreita-lhe os movimentos, assiste, impassível e fria, à sua lenta e inevitável derrota. Consciente da desgraça, com o grave pressentimento da fatalidade do destino, Arturo procura afastar os companheiros. Trata de convencê-los a deixá-lo cumprir, sozinho, a sua sorte. "Amigos meus, adverte-os, faltaria à minha consciência e à minha lealdade se não declarasse neste momento [...] que sois livres de seguir a vossa própria estrela, sem que a minha sorte vos detenha o passo. Ainda é tempo de regressar [...] Quem siga a minha rota, vai com a morte". Heli Mesa (tanto o nome como o apelido, de "origem hebraica, se prestam à identificação da personagem: Heli, "o altíssimo", Mesa, "salvação"), bom amigo, responde "por todos": "Os quatro formaremos um só homem. Não nascemos para relíquias! Ao peito, peito!" 21

Em abraço envolvente, coercivo, une-os a selva. Definitivamente. E no seu voraz torvelinho consome quantos deles se acerquem. O primeiro a aderir ao grupo é o velho Clemente Silva, rumbero de profissão, com longa experiência nos ínvios caminhos do bosque cerrado. Cova, "amigo dos débeis e dos tristes", nele vê o seu segundo Virgílio, apto a suceder a D. Rafael de quem se separara em La Maporita. As pernas ulceradas, cobertas de vermes, o miserável caucheiro conta-lhes a vida e os sofrimentos durante dezesseis anos de degredo da civilização. Vítima da selva e dos seus exploradores, Silva carrega nas costas o labéu da sua condição: na sua pele martirizada se escreve, como no tronco da seringueira, a história da Amazônia, história ingrata, de profundas e feias cicatrizes. Desconhecem-na, sempre que possível, os ricos e poderosos seringueiros. Chegam mesmo a invocar o "mal da árvore" como diagnóstico dos sinais denunciadores de violências, açoites e suplícios impostos aos caucheiros. O estigma do martírio, gra-

21. Id., ibidem, p. 130 . 
vado na carne, não é contudo a sua única riqueza. Silva transporta consigo, aonde quer que vá, um precioso tesouro: o caixão com os restos do filho, Luciano (a sua luz), vítima inocente da selva despótica. A pungente narração da sua viagem à procura de Lucianito atinge o cúlmen no grito doloroso - "Yo he sido cauchero! Yo soy cauchero!" - uma das páginas de maior intensidade dramática da literatura dos ofendidos. A todas as frustrações da vida diária, à humilhação moral e aos padecimentos físicos se soma a amarga consciência de ter sido "o herói do medíocre", obediente às ordens e às urgências do ventre vulgar. Alheio à tortura de vagar solto no cárcere da selva, o caucheiro rouba, mente e mata para enriquecer o patrão, seu verdugo. Ele e a árvore, com tormento vário, se combatem mutuamente, até sucumbir. Herói, mártir, apóstolo, ele vive e morre à sombra da mediania, suspirando, sempre, por batalhas, cataclismas, calamidades, hecatombes ... Transfere à natureza, aos elementos, às forças cósmicas e vingança que lhe caberia tomar contra o poder que o oprime. Envenenado pelo ressentimento, espera que a justiça se faça por si, por obra e graça de divindade indefinida, ou que a sua mão, habituada a sacrificar as árvores indefesas, se volte um dia contra os homens em gesto exato de punição. Só lhe resta, portanto, pobre alma de desejos que é, expressar num desabafo a sua maior aspiração: "Se Satã dirigisse esta rebelião!".22

A quantos imaginam cormucópia milagrosa a floresta tropical, pródiga e luxuriante de belezas e dons, Rivera oferece a sua visão trágica, impiedosa, cruel: árvores potentes, cativas de trepadeiras e parasitas que em curva elástica guardam no bojo frutos, flores, insetos, répteis, umidade e visgo como farnel de podridão. O mata-pau, agarrado aos troncos e galhos vigorosos, retorce-os, sufoca-os, mata-os. As terríveis tambochas, formigas vorazes, tudo destroem à passagem: plantações, animais, homens. Como um tremor contínuo agitam o solo: debaixo de troncos e raízes avançam em tumulto. "As árvores cobrem-se de uma mancha negra, como casca movediça que sobe $[\ldots]$ implacavelmente a afligir os ramos, a saquear os ninhos, a colar-se nos orifícios $[\ldots]$ " 23

22. Id., ibidem, p. 169-171.

23. Id., ibidem, p. 189. 
O hálito da morte, o marasmo da criação, o pólen que voa, o germe que brota, tudo se confunde na duração efêmera da vida orgânica. Se algum poeta sonha, ainda, "com mariposas que parecem flores translúcidas", com "pássaros mágicos" e "arroio cantor", bem depressa o desperta a crua realidade. "Nada de rouxinóis enamorados, nada de jardim versalhesco, nada de panoramas sentimentais! Aqui, o responso de sapos hidrópicos, [...] a parasita afrodisíaca que enche o solo de abelhas mortas; a diversidade de flores imundas que se contraem com palpitações sexuais e cujo odor pegajoso embriaga como droga; a liana maligna cujo pelo cega os animais; a "pinga-moça" que inflama a pele; a semente de curuju que parece globo irisado e só contém cinza cáustica, a uva purgante, o caroço amargo".

"Aqui, de noite, vozes desconhecidas, luzes fantasmagóricas, silêncios fúnebres. $\overrightarrow{\mathrm{E}}$ a morte que passa dando a vida $[\ldots]$ Esta selva sádica e virgem instiga no ânimo a alucinação do perigo próximo." 24

Nesse mundo onde se decide a cada instante a sobrevivência, onde o ciclo da vida se prende à morte numa sucessão imperceptível de mutações, câmbios e dependências, que lugar se destina ao civilizado - forasteiro, intruso e usurpador? "Paladino da destruição", ele se embrenha na floresta no intuito de dar sentido à existência estéril. Prostram-no no entanto os delírios da febre palustre, debilitam-no o clima úmido, a falta do sol, a alimentação deficiente, o trabalho exaustivo, a luta contra a natureza opressiva. Sofre "atrozes necessidades, anelando por gozos e abundância, ao rigor das intempéries", faminto e às vezes nu. Logram alguns, após tanto empenho, a independência econômica: chegam a donos de empresa. Diante da selva inimiga, sem saber a quem dar guerra, arremetem-se uns contra os outros, escravizam, torturam, subjugam. A falta de melhor emprego para a agressividade reprimida, destroem-se e trucidam-se nos intervalos da luta contra 0 bosque. A cultura, a inteligência, o refinamento do espírito pouco instruem. O único saber da redenção, válido no inferno verde, é o que subleva o homem contra o destino, vale dizer, contra a

24. Id., ibidem, p. 176. 
circunstância. A energia inerte, o tédio, a busca de $E l$ Dorado, o atavismo do avô conquistador explicam muita vez a fuga às comodidades da civilização. Não asseguram, porém, refúgio tranqüilo nem êxito brilhante aos que se aventuram na selva sem outra luz que a da própria consciência. Para certificar-nos da falência, no meio selvático, do homem de talento superior, Rivera apresenta-nos Ramiro Estévanez (Ramiro, o guerreiro?... $\overline{\mathbf{E}}$ possível.) - o super ego de Arturo Cova, nos tempos de escola. Nele marcam encontro as grandes virtudes humanas: a magnanimidade, a temperança, o otimismo (digna coroa de Estévão, "o coroado"). Amante de tudo quanto na vida é nobre - "o lar, a pátria, a fé, o trabalho", reservava para si os serenos gozos espirituais [...] conquistando da pobreza o lucro real de ser generoso". 25 Oprimido, quase cego, inútil, encontra-o Cova numa barraca do Guaracú. Não o atormenta a cegueira: aceita-a, entre cético e resignado, como castigo para os olhos enfermos de muito ver. Assistira, já, a grandes tragédias, conhecera de visu a pavorosa crônica dos seringais, padecera na própria carne a humilhação dos capatazes vaidosos cujo mérito se exalça na força e na eficácia corretiva do chicote. Ramiro Estévanez liga-se ao ex-colega e com ele e os seus empreende a fuga temerária para Yanaguarí. Determinado a partir, Cova pressente o breve término da sua senda: a ameaça da voragem já se fazia ouvir. Realmente. A sua vingança contra Barrera precipita-lhe o desencadear. Depois da "luta tremenda, muda, titânica", Arturo submerge o rival na água, impedindo-lhe a respiração. Diante do sangue, acorrem milhões de caribes. Embora sacudisse as mãos em gesto de defesa, os peixes ávidos "descarnaram-no em um segundo" [...] "Em fervor dantesco, sangrenta, túrbida, trágica", [a] "onda borbulhava; e, tal como se vê sobre o negativo a armação do corpo radiografado, foi emergindo na lâmina móvel o esqueleto limpo, esbranquiçado, semi-afundado na extremidade pelo peso do crâneo [.. ]".26 Alicia, lívida e enfraquecida, não suporta o espetáculo. Ali mesmo, nasce-lhe o filho, prematuro. "O seu primeiro grito, o seu primeiro pranto foram, na queixa do pai amargurado, para as selvas

25. Id., ibidem, p. 206.

26. Id., ibidem, p. 247. 
desumanas". Num alento de otimismo, o pensamento no filho, Cova esquece o passado. E afirma, confiante no futuro: "Viverá! Vou levá-lo numa canoa por estes rios, para a minha terra, longe da dor e da escravidão [...]" 27 .

Iluminados pela esperança, Arturo, Alicia e o menino, acompanhados dos amigos fiéis, demoram algum tempo em Yanaguarí à espera de Clemente Silva que fora em busca de socorro. A presença de portadores da peste, que chegavam com as suas montarias, obriga-os a abandonar o abrigo onde se achavam. Cova deixa para o velho Silva o seu diário e um croquis da rota que pretendiam seguir. À guisa de epílogo, comunica-nos o autor que um telegrama do Cônsul da Colômbia diz textualmente o seguinte: "Faz cinco meses busca-os em vão Clemente Silva. Nem rasto deles. Devorou-os a selva!"

Essa, em vôo de pássaro, a intriga de La vorágine. Valendo-se do recurso cervantino do encontro de um manuscrito - o diário do poeta Arturo Cova, devorado pela selva, conta-nos Rivera a sua história. Duas cartas servem de prólogo ao romance: a primeira, assinada pelo protagonista e dirigida a Cônsul da Colômbia, a segunda, do autor, responsável pela publicação dos originais, ao Ministro das Relações Exteriores, interessado na divulgação dos escritos do infeliz caucheiro.

Os críticos descobriram em La vorágine rasgos evidentes de autobiografia. E incumbiu-se o escritor, ingenuamente talvez, de confirmar-lhes a hipótese: fez reproduzir, numa das primeiras páginas do livro, um retrato seu, na selva, com o nome de Arturo Cova. Em entrevista a Horácio Franco, em Cali, à questão "La vorágine, mestre, é efetivamente uma realidade?", concordou: "Na sua quase totalidade. Vi todas essas coisas. As personagens que ali figuram são todas criaturas vivas e algumas delas com os seus próprios nomes." 28

Há, pois, dois níveis na estrutura narrativa: um, real, vivido; o outro, fictício. No nível da realidade situa-se o protesto social, a defesa destemida dos caucheiros colombianos, privados de toda pro-

27. Id., ibidem, p. 248.

28. El Relator, 23-08-1926. 
teção oficial, vilmente explorados pelos empresários dos cauchais, pelas casas aviadoras e pelos enganchadores ou contratadores das grandes companhias.

A organização do romance obedece às necessidades de organização do itinerário do herói. Somos espectadores de uma perspectiva em movimento: a sucessão de quadros corresponde ao trânsito do protagonista, bem como ao desdobramento das personagens de que resulta a elaboração de novos episódios. O material narrativo depende, em consequiência, da tessitura episódica e atende, também, à circunstância de tempo e lugar. A viagem - a longa travessia da selva -, inspira-se no desejo de vingança (stimulus) contra Barrera, e na procura de Alicia. Os obstáculos e dificuldades, que exigem do herói coragem e valor, favorecem o aprendizado. Arturo aprende, amadurece, faz-se adulto. Os seus guias - D. Rafael, sexagenário e companheiro do pai, Clemente Silva, ancião venerável que lhe lembrava o pai; os amigos - Fidel Franco, Heli Mesa, Ramiro Estévanez; os inimigos - Pipa, Millán, o Váquiro, Funes, o Cayeno, Barrera; as mulheres - Griselda, Clarita, Zoraida Ayram, assumem, todos eles, a missão de ensinar-lhe a vida. É o romance da educação, da lição - Bildungsroman.

Identificam-se, à maravilha, Alicia e a selva. Virgens, ambas; violadas, mas indomáveis. Jovem e impulsivo, Arturo menospreza a companheira. Ao sabê-la grávida, observa-lhe o comportamento, julga-a distintamente, passa a estimá-la. Ao perdê-la, descobre que a amava. Desespera-o a solidão. Começa, então, a ansiosa procura. Eis, em fases que se sucedem, em cadeia, o típico desnovelar da busca - the quest, estudado por Northrop Frye. Sob os efeitos da ausência, transfigura-se a imagem da amada. A memória depura-lhe os traços, afeiçoa-lhe o caráter. A demanda impossível adquire, paulatinamente, maior importância que o objeto procurado. Alicia transforma-se em pretexto. Arturo, confundido, perde-se em alucinações. Dois sonhos, de transparência freudiana, ajudam-nos a compreender as intenções do novelista.

Vejamos: no primeiro deles, Alicia, sozinha, vai ao encontro de um homem, Barrera, certamente. Vigilante, a espingarda em punho, rejeitado e traído, Cova acorda para a vingança. Tenta dirigir a arma contra o sedutor da amante mas ela se converte numa serpente gelada e rígida. D. Rafael, o velho guia, acena-lhe 
com o chapéu e diz: "Venha! Já não há remédio!" Em seguida, sem transição, um novo quadro: num país estranho, Griselda, mulher de Franco, aparece no cimo de uma penha de onde flui o líquido esbranquiçado do cauche. Por todas as partes, gente sedenta, de bruços, bebe-o sem contudo fartar-se. Franco, sobre um promontório de carabinas, admoesta: "Infelizes, atrás da selva está o além!" Ao pé de cada árvore há um cadáver à espera do enterro. Cova recolhe-os, um a um, para exportá-los num rio silencioso e escuro. Alicia, novamente, nua e desgrenhada, foge de Cova por entre os arbustos do bosque noturno, iluminado por pirilampos colossais. Uma acha à mão, no cinto um recipiente de metal, Arturo detém-se em frente de uma araucária, parecida com a árvore do caucho. Faz várias incisões no tronco. A árvore, ferida, pergunta-lhe: "Por que me sangras? Eu sou a tua Alicia convertida em parasita".

Percebe-se, isso posto, que Eros e Thanatos conjuram forças contra o homem impotente. Os símbolos fálicos - a espingarda, as carabinas, a acha não o socorrem. A lâmina afiada corta o tronco da árvore que, violada, o repreende e lhe revela ser Alicia, convertida em planta. A referência ao promontório de carabinas, sem uso, sobre o qual se vê Franco, o fiel (Fidel), evidencia a ineficácia do esforço, o malogro da virilidade. Atrás da selva, há, para todos, "el más allá". O fio esbranquiçado de goma se perde sem dessedentar os infelizes que se lançam ao chão para bebê-lo. O látex precioso confunde-se com o sêmen: é a vida em fuga, é a energia de que falecem os impotentes para a conquista e a posse da selva virgem.

No segundo sonho Cova imagina-se morto. Em estado cata. léptico, luta contra o corpo imóvel e tenta esquivar-se dos golpes desferidos contra a sua cabeça por uma sombra vingadora. A selva rebelde tortura-o, martiriza-o. Até que Franco o desperta do pesadelo. A morte sofrida livra-o, como se vê, do incômodo sentimento de culpa. A árvore violada, indiferente à revelação de que ainda está vivo, ordena à sombra assassina: "Picai-o, picai-o com o vosso ferro para que experimente o que é a lâmina na carne viva. Picai-o embora indefeso pois também ele destruiu as árvores e é justo que reconheça o nosso martírio." 
Parece-nos ocioso insistir na estreita relação entre os dois sonhos. Suficientemente explícita, ela autoriza o sentimento de culpa do herói na notória dependência freudiana do crime ao castigo .

As figuras femininas do romance desempenham papel de relevo nos três momentos de crise de vida do protagonista. Alicia, apresentada à primeira página, surge como pretexto para o desencadear do fatum. A idéia do jogo - "Joguei o meu coração ao acaso [...]" - contida no parágrafo introdutório, lhe é sugerida como solução para o caso amoroso. A amante, a quem sacrificara a carreira, brilhantemente iniciada, parece-lhe carga indesejável, estorvo. O seu maior desejo? Que alguém os capture para livrar-se do compromisso e recuperar a liberdade empenhada. O amor arma-lhe, a contragosto, cilada astuciosa: a indiferença da companheira incita-lhe a paixão. Começa a idealizá-la, veste-a de encantos antes ignorados, curva-se aos sortilégios da própria imaginação. Quando da sua partida com Barrera, é a paixão que o move à vingança. $\overline{\mathrm{E}}$ ela, ainda, que o repta a dar provas de virilidade à selva virgem. Sobre Arturo (paladino celta, cavaleiro de muitas provas), a amada ofendida (Alicia, tragada pelo poço... ou pelo abismo?) exerce poder aliciante. Clarita surge no momento da decisão. O jogo, anteriormente mencionado como azar, fado, torna-se realidade, fato. Decide-se nos dados, perante a prostituta ingênua, desinibida (Clara, Clarita), a vida de Arturo. Salvo da morte por milagre, acompanha Franco a La Maporita. Ali, transfere-se ao fogo a missão mundificadora. "O estalido dos arbustos, o coro ululante das serpentes e das feras, o tropel do gado apavorado, o cheiro amargo de carnes queimadas [abrigaram-me] a soberba", comenta. E senti deleite, continua, por tudo que morria atrás da minha ilusão, por esse oceano purpúreo que me lançava contra a selva, afastando-me do mundo que conheci, num incêndio que estendia a sua cinza sobre os meus passos [...] No meio das chamas comecei a rir como Satanás!" 29

Assim termina a primeira parte. Consome-se no incêndio o mundo civilizado. Abrem-se ferozes as fauces da selva devoradora,

29. La vorágine, cit., p. 93 . 
pronta a envolver na sua voragem os que tentam devassar-ihe os domínios.

No cenário brutal onde a vida humana tem menor preço que a tijelinha de látex, e onde a morte significa alívio e libertação, pontifica Zoraida Ayram (Zorra airada? loba airada? Talvez...), fêmea bestial e calculadora. Funda-se o seu império, de vício e cupidez, na fraqueza dos homens. "Pelos rios mais solitários, pelas correntes mais perigosas, atrevia o seu batelão em busca dos caucheiros para trocar por quinquilharias a goma roubada, expondo-se a violências de toda espécie, à traição da própria tripulação, ao fuzil dos salteadores, desejosos de acumular centavo por centavo a fortuna com que sonhava, ajudando com o corpo quando o bom êxito do negócio o exigia. Para enfeitiçar os homens selváticos, ataviava-se com grande esmero, e ao desembarcar nos barracões, limpa, cheirosa, confiava a defesa dos seus haveres à sua convidativa sensualidade." 30

O esgotamento lúbrico, a astenia do vigor físico prostram o protagonista, já enfraquecido pelas febres. Exausto pela loba famélica que trata de oxidar com erotismo as suas últimas energias, Arturo "sente a nostalgia da mulher ideal cujos braços brindem serenidade para a inquietude, refrigério para o ardor, olvido para os vícios e paixões". Ao lado da turca sensual, ele sonha com Alicia, a companheira tímida.

O reencontro em Yanaguarí, no final da travessia, encerra o périplo trágico. As lembranças perdidas no rio escuro, a memória do passado reduzida a cinzas em La Maporita, resta a Arturo Cova a incerta opção do futuro. Encarna-o o filho, recém-nascido. Futuro mirrado, esse, mesquinho e raquítico, recolhido no corpo débil do setemesinho, limitado à parca economia de víveres para seis dias (no sétimo, o descanso).

Em nome de Deus conclui-se o seu diário. Mas, a exemplo da Divina Commedia, cabe à voracidade satânica o epílogo do inferno verde:

"Los devoró la selva".

30. Idem, ibidem, p. 199. 